\title{
THE CURRENT STATE OF PROJECT RISK ASSESSMENT AND EDUCATION NEEDS IN PROJECT RISK MANAGEMENT

\author{
Matej Masár ${ }^{1}$, Mária Hudáková ${ }^{2}$
}

\begin{abstract}
Current trends show that education in the field of project risk management is a very actual topic. Long - term projects, which was realized in 2018, was mainly focused on R\&D across the world. Short - term projects, was focused on innovation and improve manufacturing processes. Many projects failed because project managers did not manage project risks. Project managers have less knowledge and skills on how to effectively manage project risks, especially risks in the planning phase of projects.

The main aim of this article is to analyze the current state of usage project risk assessment across the world, based on own empirical research, which was provided, by authors in 2018 and 2019 (mainly level of usage project risk management methods, experience and level of education). The research focused on analyzing the current state of project risk assessment among continents. The authors focused on the average level of use qualitative and quantitative project risk analysis by project managers, level of project risk management experience by project managers and complexity of learning in using of qualitative and quantitative project risk management methods and tools. Some recommendation were established to educate project managers in the field of project risk management.
\end{abstract}

JEL Classification Numbers: G32, L21, M21, O22, DOI: 10.12955/cbup.v7.1363

Keywords: risk, project, enterprise, education, risk assessment, research

\section{Introduction}

It is possible to perceive a global current trend which is based on the implementation of new technology known as the smart industry, smart manufacturing, internet of things, enterprise smart digitalization, etc (Hudakova, 2018). Enterprises want to be more and more competitive, so they innovate, educate their employees, produce new modern products, and follow actual trends and customer requirements. One of the actual trends is the conception of Industry 4.0. This conception is focused on digitalization and use of smart devices across the enterprise. The implementation of Industry 4.0 into enterprises is realized by short term projects. Most of them fail because project managers have less skills and knowledge in the field of project risk management.

The main aim of this article is to analyse the current state of usage project risk assessment across the world, based on own empirical research, which was provided, by authors in 2018 and 20192019 (mainly level of usage project risk management methods, experience and level of education). This research was focused on analyzing the current state of project risk assessment among continents.

\section{Literature review}

A risk-free project is fiction. Every project obtains positive and negative risks. Nowadays projects by PMI (2018), Software Advice (2013) and KPMG (2017) are characterized with an increasing number of risks, increasing number of involved project members, unclear project outputs, high customer expectations, and high costs. Project managers must use the methodology or approach which is best suited for the project. They must realize all steps of project risk management and use methods and techniques, which are necessary to identify and assess project risks. Software support is necessary for project risk management, too.

Worldwide institutions (KPMG, 2017; E\&Y, 2017; PMI, 2018; Software advice, 2013; Farooq, Thaheem et al., 2018) conducted surveys which were focused on finding the current state of project management and project risk management. Based on the results of the mentioned surveys it is possible to summarize and establish the following:

- Improper management is the most frequent reason why projects fail mainly in the planning or initializing phase of the project.

- Plans of Man-Power are inappropriately defined too.

- Poor project risk management is the greatest mistakes in each phase of the project's lifecycle.

- It appeared mistakes in the project as poor communication, change of project priority and resource utilization in 2017 too.

\footnotetext{
${ }^{1}$ University of Žilina, Faculty of Security Engineering, Department of Crisis Management, Žilina, Slovakia, matej.masar@fbi.uniza.sk

${ }^{2}$ University of Žilina, Faculty of Security engineering, Department of Crisis Management, Žilina, Slovakia, maria.hudakova@ fbi.uniza.sk
} 
- Financial loses influenced many projects in 2017 too. It was determined that with each 1 billion dollars that was invested the loss was 97 million dollars, therefore representing a reduction of $20 \%$ in value of the investment compared with the last year (PMI, 2018; Zhang et al., 2018, Soviar, 2018).

- Project managers fail in 50\% of cases because they do not use the correct procedure for using methods and techniques.

\section{Research methodology}

Based on the literature review, the research is focused on understanding the degree of skills of project managers across the world in the field of risk management in enterprises. Project managers rate characteristics in scale from 1 (the lowest; the worst) to 10 (the highest).

The main research questions which were established, are:

- Q1: What is the level of usage of quantitative risk assessment methods by project managers among different continents?

- Q2: What is the level of usage of qualitative risk assessment methods by project managers among different continents?

- Q3: What is the level of project risk management experience that project managers have among different continents?

- Q4: What is the level of complexity of learning in using qualitative project risk analysis methods and tools perceived by project managers among different continents?

- Q5: What is the level of complexity of learning in using quantitative project risk analysis methods and tools perceived by project managers among different continents?

The main methodology of this study was the use of a survey, which targeted project managers that carry out projects in enterprise. The research questions will be testing by basic statistic indicators (using descriptive statistics).

The questionnaire was divided into three main sections 1. Project management, 2. Project Risk management and 3. Project risk management support. Section 1 is focused on the main project management methodologies, project management tool usage, frequency of use of main project management processes, standardization of project management processes and project managers characteristics. Section 2 analyses the usage of main project risk management methodologies, the frequency of risk management steps used during project planning, the most commonly used project risk management tools that are used to identify and analyse project risks and percentage of acceptable impact and the probability of project risks. Section 3 is focused on the most used software support in the process of project risk management.

Reliable of the survey was calculated with a formula for an established sample size of survey respondents provided by Barlett et al., (2011), who used Cochran's formula for an established reliable sample. The minimum sample size using this formula is 1037 (for confidence level $99.50 \%$ and margin of error which is accepted of $4 \%$. The estimated number of project managers across the world is 10000 000 (Masar, 2019). 1225 project managers participated in this research. Based on this, it is possible to consider the results of the survey as reliable.

The survey group was established by the main aim of research. The group consisted of project managers which managed projects in small, medium, and large sized enterprises in the continents - Europe (66.1 $\%)$, Africa $(11.4 \%)$, Asia and Australia $(7.5 \%)$ and America (14.9\%). The questionnaire was distributed by social networks - LinkedIn ${ }^{\circledR}$, Projectmanagement.com and by the Academy of International business.

\section{Results}

The 1225 project managers responded to the out of whome 108 project managers were from Africa and the Middle East, 167 project managers from America, 137 project managers from Asia and Australasia and 808 project managers form Europe and Russia. The project managers sruveyed managed primarly projects which are realized in enterprises $(78.4 \%)$, information technology $(5.9 \%)$, agriculture and farming (5.7\%), transport (4\%), transport services (3.6\%), construction $(0.7 \%)$, financial services $(0.6$ $\%)$ and Health services $(0.3 \%)$. 


\section{Testing Research Question Q1}

Current trends show that a quantitative risk analysis is the most used in Europe. Project managers use a quantitative risk analysis to determine the established level of risk impact in a project. Trends are made through the use of surveys, which are summaries for long term projects (realized more than 1 year) and for short term projects (less than 1 year).

\begin{tabular}{|c|c|c|c|c|}
\hline Basic statistic indicators & $\begin{array}{c}\text { Africa and Middle } \\
\text { - East }\end{array}$ & America & $\begin{array}{c}\text { Asia and } \\
\text { Australasia }\end{array}$ & Europe and Russia \\
\hline Mean & 4.9815 & 3.9162 & 3.6058 & 3.0173 \\
\hline Standard Error & 0.1380 & 0.0666 & 0.0522 & 0.0376 \\
\hline Median & 6.0000 & 4.0000 & 4.0000 & 3.0000 \\
\hline Mode & 6.0000 & 3.0000 & 4.0000 & 2.0000 \\
\hline Standard Deviation & 1.4338 & 0.8602 & 0.6107 & 1.0699 \\
\hline Sample Variance & 2.0557 & 0.7399 & 0.3729 & 1.1447 \\
\hline Kurtosis & -1.3461 & -1.2009 & -0.3519 & 5.1258 \\
\hline Skewness & -0.6842 & 0.2202 & 0.0773 & 1.6087 \\
\hline
\end{tabular}

Source: Authors

Based on the results, project managers in Africa and the Middle East use the most qualitative project risk analysis in short time projects. Table 1 shows that project managers in Africa and the Middle East use qualitative project risk rather (by results of median and mode).

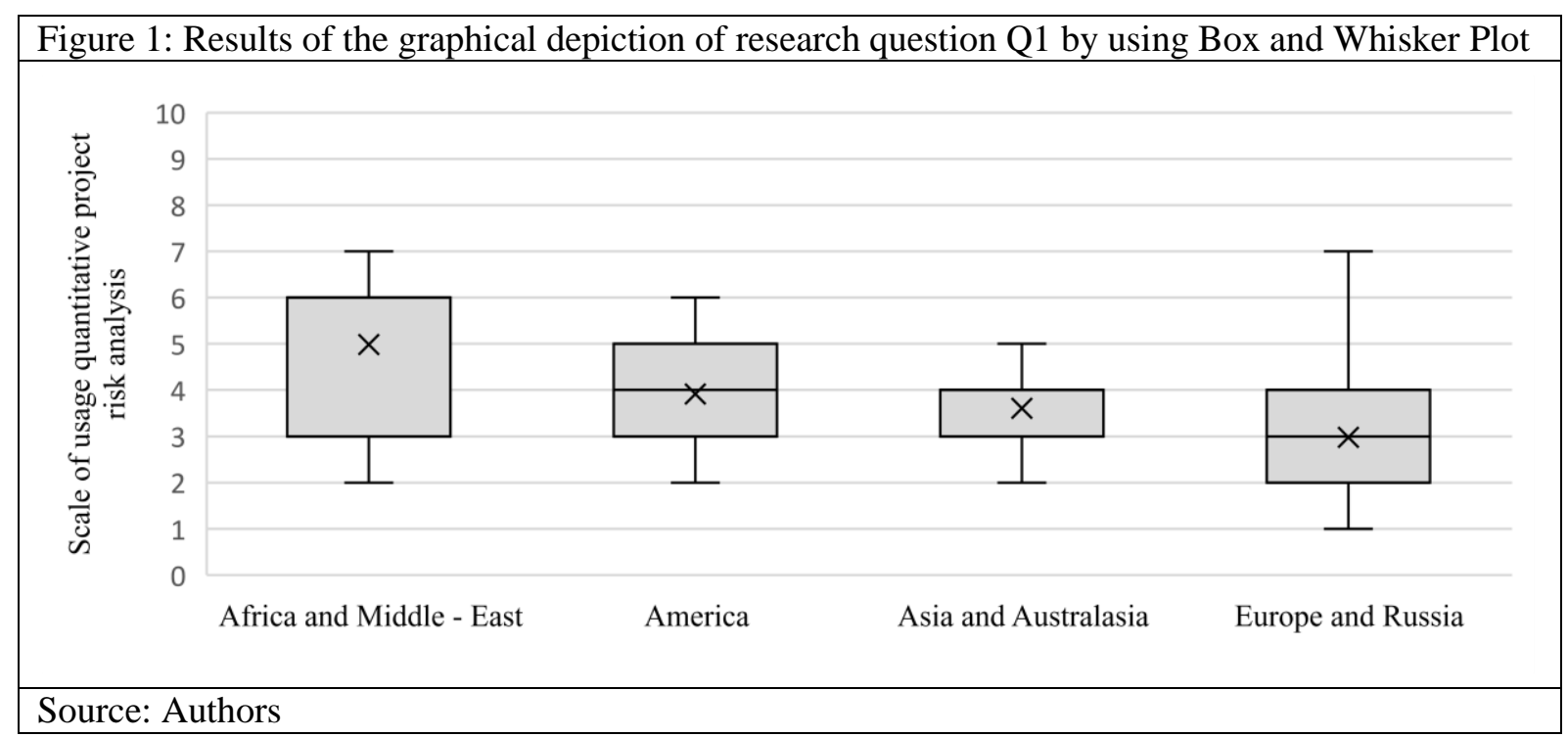

Based on Figure 1, it is possible to say that the highest level of quantitative project risk management usage is in Africa and the Middle East while in Europe and Russia it is the least.

\section{Testing Research Question Q2}

Current trends show, that the qualitative risk analysis is most used in America. Project managers use qualitative risk analysis to determine the established level of risk impact and likelihood in the project. Trends are made through the use of surveys, which are summaries for long term projects (realized more than 1 year) and for a short term projects (less than 1 year), too.

Based on the results, project managers in America use the most qualitative project risk analysis in short term projects.. Table 2 shows that project managers in America use qualitative project risk analysis rather (by results of median and mode).

On Figure 2, it is possible to see some outliers, but based on the research question, is possible to calculate the results, with the outliers. Based on Figure 2, it is possible to say that the average level of qualitative project risk analysis use by project managers in America is the highest. The highest level of qualitative project risk management usage is in America, while in Asia and Australasia it is the least. 
Table 2: Basic statistic indicator for confirm or Research Question Q2

\begin{tabular}{|l|c|c|c|c|}
\hline Basic statistic indicators & $\begin{array}{c}\text { Africa and Middle - } \\
\text { East }\end{array}$ & America & $\begin{array}{c}\text { Asia and } \\
\text { Australasia }\end{array}$ & $\begin{array}{c}\text { Europe and } \\
\text { Russia }\end{array}$ \\
\hline Mean & 3.7407 & 3.8144 & 3.1606 & 3.2401 \\
\hline Standard Error & 0.0669 & 0.0763 & 0.0510 & 0.0342 \\
\hline Median & 5.0000 & 3.0000 & 3.0000 & 4.0000 \\
\hline Mode & 5.0000 & 3.0000 & 3.0000 & 3.0000 \\
\hline Standard Deviation & 0.6948 & 0.9856 & 0.5970 & 0.9726 \\
\hline Sample Variance & 0.4828 & 0.9714 & 0.3564 & 0.9460 \\
\hline Kurtosis & 5.2632 & -1.6095 & 17.7721 & 5.1445 \\
\hline Skewness & 1.2732 & 0.4195 & 3.9312 & 1.5701 \\
\hline
\end{tabular}

\section{Source: Authors}

Figure 2: Results of the graphical depiction of Research Question Q2 by using Box and Whisker Plot

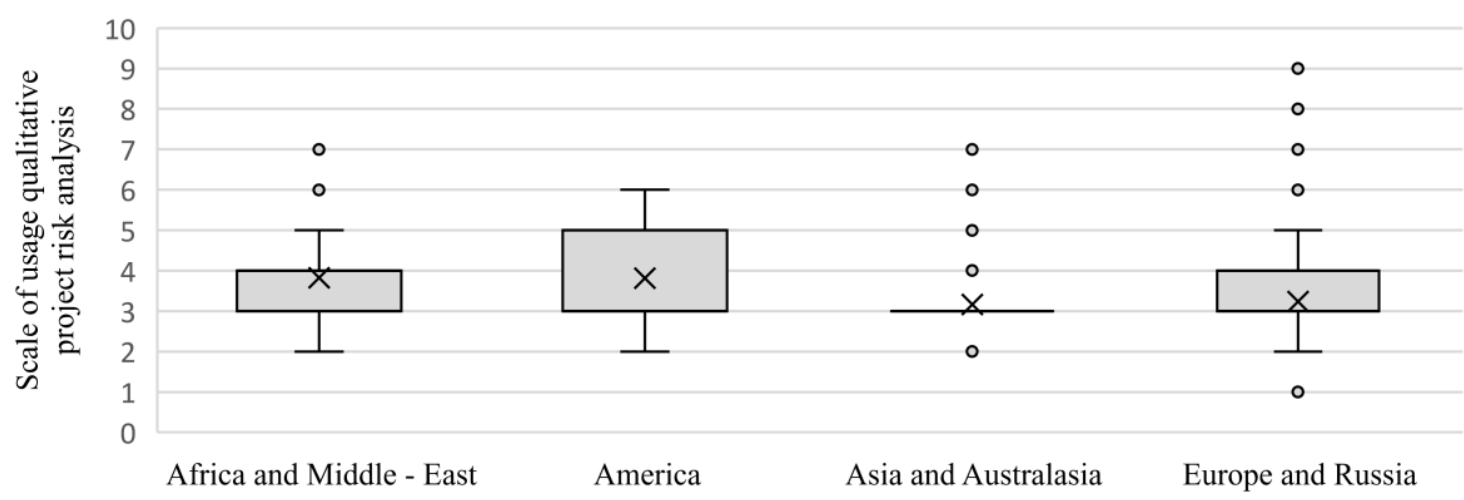

Source: Authors

\section{Testing Research Question 3}

Project managers perceived a need to educate in the field of risk management. Based on several research is an education in the field of project risk managers contemporary trend. If project managers use project risk management in the correct form, they may save money and explore advantages which are in the project. The surveys made a summary for long term projects (realized more than 1 year) and for short term projects (less than 1 year). Asia is best known as one of the best continent in research and development of IT and electrotechnical devices. So, it is possible to predict that project managers have a lot of skill with project risk management in this country.

\begin{tabular}{|l|r|r|r|r|}
\hline Table 3: Basic statistic indicator for Research Question Q3 \\
\hline Basic statistic indicators & $\begin{array}{c}\text { Africa and Middle } \\
\text { - East }\end{array}$ & America & $\begin{array}{c}\text { Asia and } \\
\text { Australasia }\end{array}$ & $\begin{array}{c}\text { Europe and } \\
\text { Russia }\end{array}$ \\
\hline Mean & 4,7407 & 4,1497 & 3,7445 & 3,8837 \\
\hline Standard Error & 0,0771 & 0,0500 & 0,0672 & 0,0401 \\
\hline Median & 5,0000 & 4,0000 & 4,0000 & 3,0000 \\
\hline Mode & 5,0000 & 4,0000 & 4,0000 & 3,0000 \\
\hline Standard Deviation & 0,8015 & 0,6459 & 0,7862 & 1,1402 \\
\hline Sample Variance & 0,6424 & 0,4172 & 0,6181 & 1,3000 \\
\hline Kurtosis & 6,6041 & 25,7312 & 6,3014 & 1,8531 \\
\hline Skewness & $-0,2710$ & 4,7362 & 1,7768 & 1,3506 \\
\hline
\end{tabular}

Source: Authors

Based on the results, project managers in Africa and the Middle East have the highest average level of project risk management experience. Table 3 shows, that project managers in Africa and the Middle East have the highest average level of project risk management experience rather (by results of median and mode). 


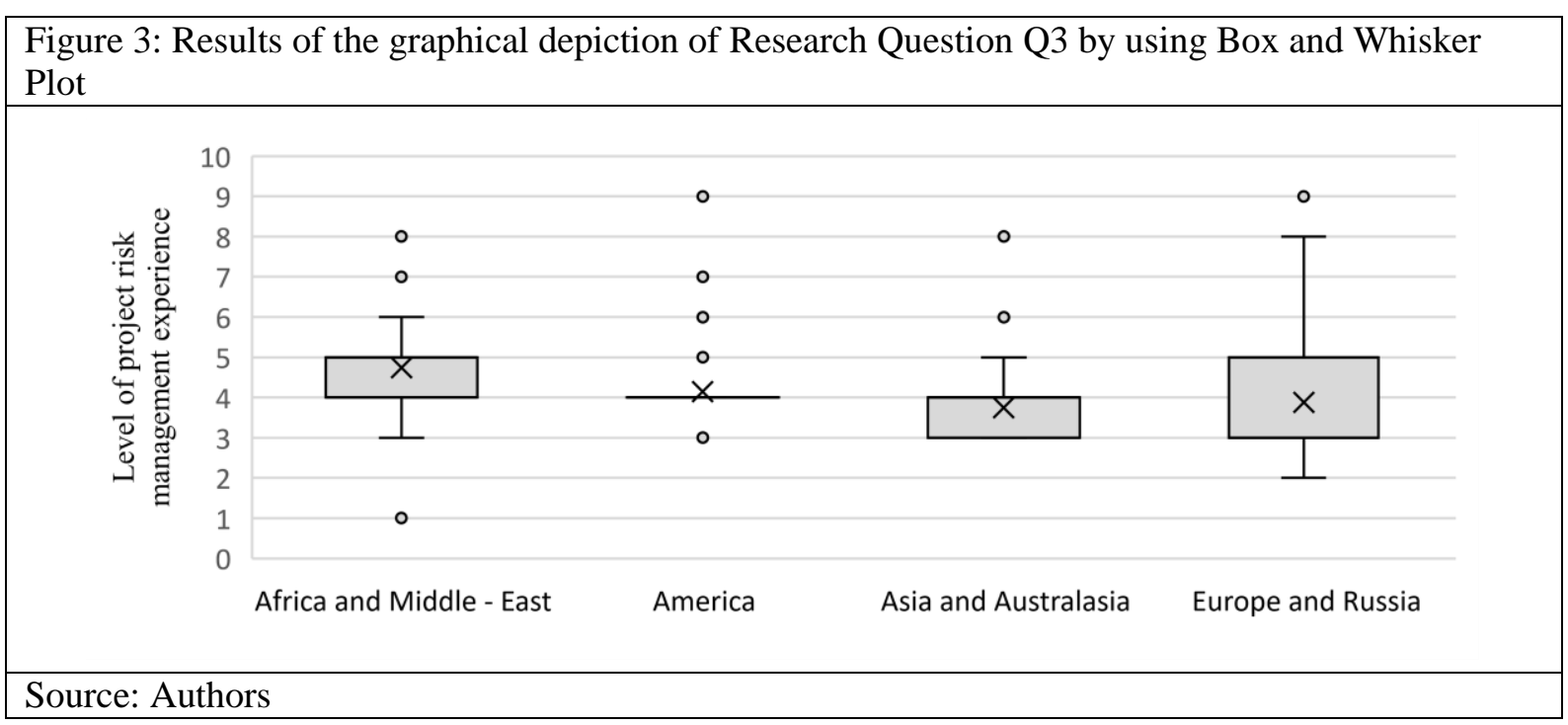

In Figure 3 it is possible to see some outliers, but based on the research objective, is possible to calculate results with them. Based on Figure 3, it is possible to say that the highest average level of project risk management experience is seen in project managers in Africa and the Middle East, while in Asia and Australasia it is the least.

\section{Testing Research Question Q4}

Current project risk management standards and methodology which are focused on short term projects, describe the importance of qualitative project risk analysis in these projects. Project managers, by many authors, rather use qualitative analysis than quantitative analysis in projects. Research shows on this fact, but surveys are usually provided as a summary for long term projects (realized more than 1 year) and for short term projects (less than 1 year).

Based on the results, project managers in America perceived the most complexity of learning in using qualitative project risk management methods and tools. In general it is possible to say that project managers across the world perceived the need to educate in the field of project risk management especially qualitative analysis.

In Figure 4 it is possible to see some outliers, but based on research objective is possible to calculate results with them. Based on Figure 4, it is possible to say the most complexity of learning in using of qualitative risk management methods and tools is perceived by project managers who run projects in America, while Asia and Australia is the least.

\section{Testing Research Question Q5}

Current project risk management standards and methodology which are focused on long term projects, describe the importance of quantitative project risk analysis in this project. Project managers rather use qualitative analysis if they want to established the likelihood or impact of project risks, project portfolio risk or project program risk. Research shows this fact, but surveys are usually provided as a summary for long term projects (realized more than 1 year) and for short term projects (less than 1 year).

\begin{tabular}{|l|r|r|r|r|}
\hline \multicolumn{2}{|l|}{ Table 4: Basic statistic indicator for Research Question Q4 } \\
\hline Basic statistic indicators & $\begin{array}{c}\text { Africa and Middle } \\
\text { - East }\end{array}$ & America & Asia and Australasia & $\begin{array}{c}\text { Europe and } \\
\text { Russia }\end{array}$ \\
\hline Mean & 4,2037 & 4,7605 & 3,8905 & 4,3502 \\
\hline Standard Error & 0,0753 & 0,0837 & 0,0987 & 0,0482 \\
\hline Median & 4,0000 & 4,0000 & 3,0000 & 4,0000 \\
\hline Mode & 4,0000 & 4,0000 & 3,0000 & 4,0000 \\
\hline Standard Deviation & 0,7825 & 1,0822 & 1,1548 & 1,3696 \\
\hline Sample Variance & 0,6123 & 1,1712 & 3,3335 & 1,8759 \\
\hline Kurtosis & 16,4951 & 1,4003 & 1,5542 & 0,6455 \\
\hline Skewness & 3,6775 & 1,1545 & 0,9755 \\
\hline Source: Authors & & & &
\end{tabular}




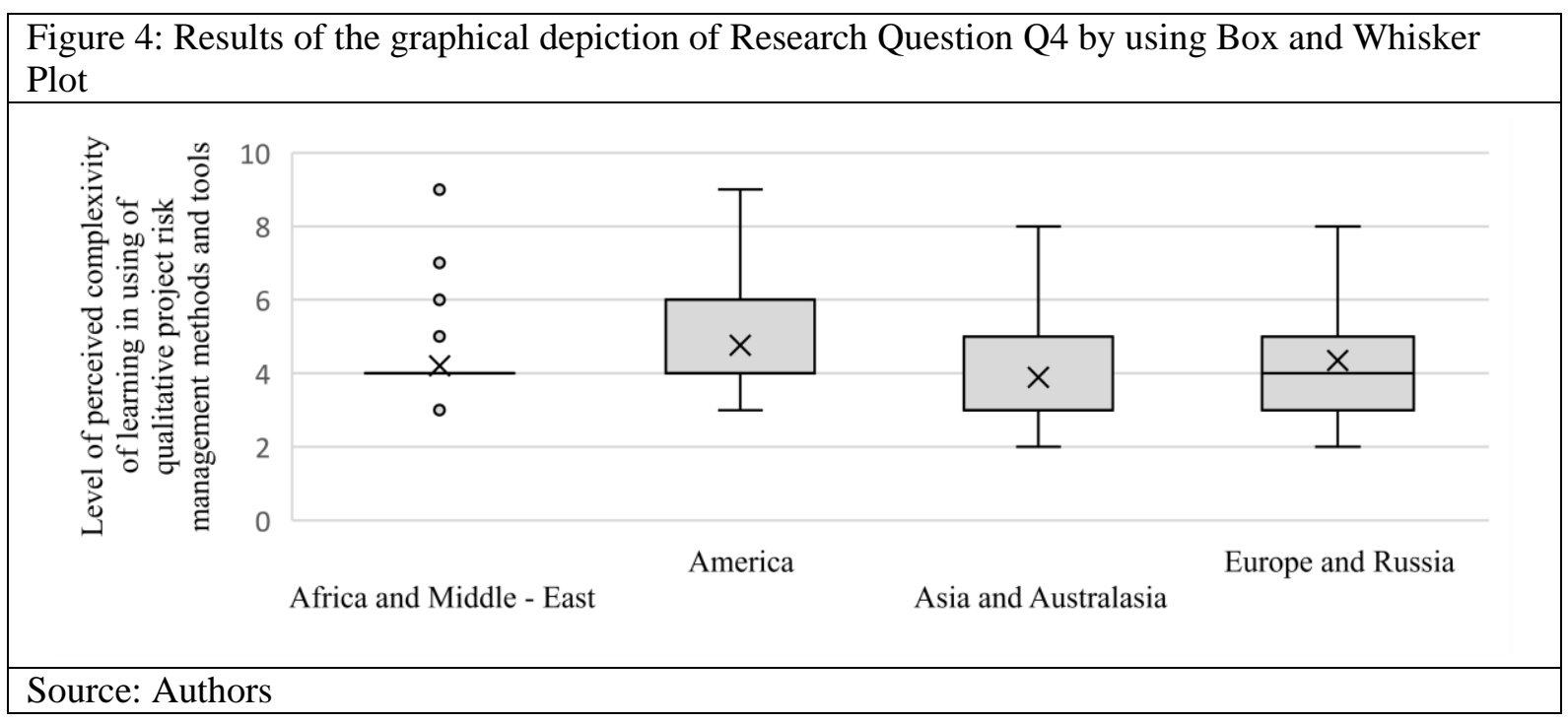

\begin{tabular}{|l|r|r|r|r|}
\hline \multicolumn{6}{|l|}{ Table 5: Basic statistic indicator for Research Question Q5 } \\
\hline \begin{tabular}{|l|r|r|r|} 
Basic statistic indicators \\
Mean
\end{tabular} & $\begin{array}{c}\text { Africa and Middle } \\
\text { - East }\end{array}$ & \multicolumn{1}{c|}{ America } & $\begin{array}{c}\text { Asia and } \\
\text { Australasia }\end{array}$ & $\begin{array}{c}\text { Europe and } \\
\text { Russia }\end{array}$ \\
\hline Standard Error & 0.0463 & 4.2754 & 4.1314 & 4.2809 \\
\hline Median & 4.0000 & 0.1526 & 0.0781 & 0.0568 \\
\hline Mode & 4.0000 & 3.0000 & 4.0000 & 4.0000 \\
\hline Standard Deviation & 0.6751 & 3.0000 & 4.0000 & 3.0000 \\
\hline Sample Variance & 0.4558 & 1.9717 & 0.9141 & 1.6151 \\
\hline Kurtosis & 29.0084 & -1.1319 & 5.8356 & 2.6087 \\
\hline Skewness & 3.6583 & 0.5069 & 1.3179 & -0.1393 \\
\hline Source: Authors & \multicolumn{5}{|l}{} \\
\hline
\end{tabular}

Based on the results, project managers in Europe perceived the most complexity of learning in using quantitative risk management methods and tools. In general it is possible to say that project managers across the world perceived the need to educate in the field of project risk management especially quantitative analysis.

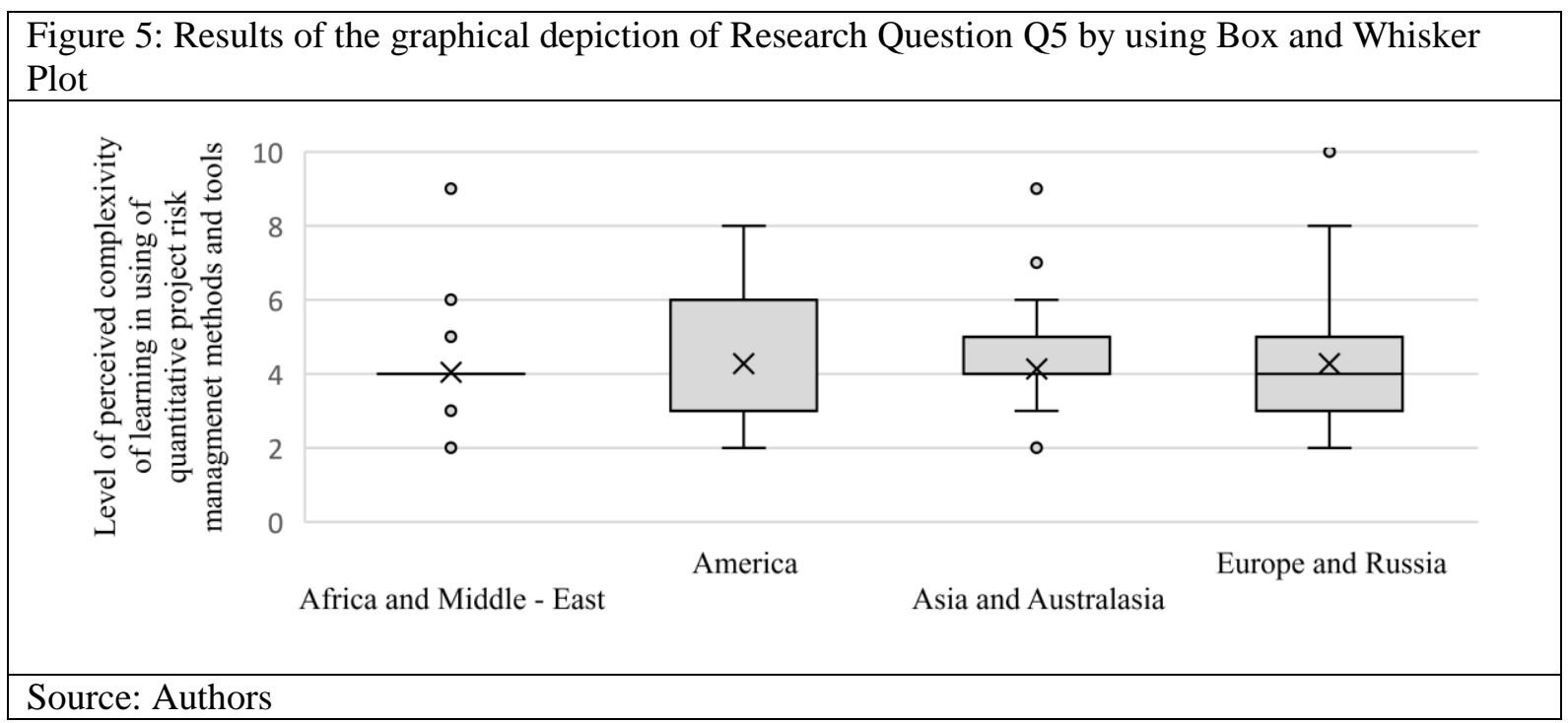

Based on the results, it is possible to interpret Figure 5. Project managers in Europe perceived the most complexity of learning in using quantitative risk management methods and tools. The most complexity of learning in using quantitative project risk analysis methods and tools is perceived by Project Managers who run projects in Europe. But at least the average level of the perceived complexity of learning in 
using quantitative risk management methods and tools is in Africa and Middle - East. In general it is possible to say, that project managers across the world perceived the need to educate in the field of project risk management especially quantitative analysis.

\section{Conclusion}

The current need for education in the field of project risk management is the actual topic. It is necessary to educate project managers in the field of project risk management, especially in the use of project risk management methods and techniques in the phase of risk assessment.

The authors determined that:

- the highest level of quantitative project risk management usage is in Africa and the Middle East, while it is the lowest in Europe and Russia.

- the highest level of qualitative project risk management usage is in America, while it is the lowest in Asia and Australasia.

- the highest average level of project risk management experience is seen in project managers in Africa and the Middle East.

- the most complexity of learning in using qualitative risk management methods and tools is perceived by project managers who run projects in America.

- the most complexity of learning in using quantitative project risk analysis methods and tools is perceived by Project Managers who run projects in Europe.

Based on the results of the empirical study, it is necessary to take care of education in the field of risk management especially project risk management. School institutions may create new study fields which can be focused on risk management. This may improve enterprise competitiveness and project managers may hence run projects more efficiently.

It is possible to recommend that project managers take care of their own education in the field of project risk management because the current level of risk management usage in projects (in the empirical research) is very lacking. If risk management, especially project risk assessment, is used in projects it can bring lot of benefits:

- project risk assessment may help to avoid project failures (if project managers identify major risks, and create successful strategies),

- entrances revenues by saving costs,

- gives more competitiveness,

- explore new opportunities in projects.

It is possible to consider project risk management as an important tool for project management. In many cases is insufficient project risk management disagreements as lack of founds and unskilled staff at the bedside. Realized empirical research point on less skills in the project risk managers in the world in manufacturing sectors in short term projects. Project managers inadequate use of professional risk management techniques, procedures and tools for manage risks.

Courses which teach project risk management may be more oriented to gain practical skills and practical use project risk assessment especially tools and technique for project risk identification and qualitative and quantitative analysis, which may improve project managers to improve better results of projects outputs.

Current trends and requirement for project managers by standards (ISO, PMI, PRINCE 2, IPMA), require the use of project risk management in the process of project management. Based on this, and the research conclusions, it is necessary to educate project managers in the field of project risk management.

\section{Acknowledgment}

Publication of this paper was supported by the Scientific Grant Agency - the project KEGA No. 030ŽU4/2018 and the Internal Grant Scheme of Faculty of Security Engineering, the University of Zilina from the grant No. 201801.

\section{References}

Bartlett, J. E., Kotrlik, J. W. and Higgins, C. C., 2011. Organizational Research: Determining Appropriated Sample Size in Survey Research, Information Technology, Learning, and Performance Journal, Vol. 19, No. 1, pp. 43-50.

E\&Y., 2017. Ernest \& young. Výsledky pruzkumu projektového řízení v České republice a na Slovensku za rok 2017.

[Online]. Available: http://www.ey.com/. 
Farooq, M.U., M. J. Thaheem, et al., 2018. Improving the risk quantification under behavioural tendencies: A tale of construction projects. International Journal of Project Managment. vol. 36 (3), pp. 414-428.

Hudakova, Maria; Masar, Matej, 2018. The Assessment of Key Business Risks for SMEs in Slovakia and Their Comparison with other EU Countries. In: ENTREPRENEURIAL BUSINESS AND ECONOMICS REVIEW Volume: 6 Issue: 4. Pages: 145-160. DOI: 10.15678/EBER.2018.060408

KPMG, 2017. Driving business performance-Project management survey 2017. [online]. Available: https://www.pmi.org//media/pmi/documents/public/pdf/learning/thought-leadership/pulse/pulse-of-the-profession -2016.pdf?sc_lang_temp=en Masár, M., Hudakova, M., 2019. Project risk management in the context of industry 4.0 in condition of manufacturing enterprises in Slovakia. In: Conference: International Scientific Conference on The Impact of Industry 4.0 on Job Creation. Pages: 145-154

PMI, 2018. Project Management Institute. Success Rates Rise - Transforming the high cost of low performance. [Online]. Available: https://www.pmi.org/learning/thought-leadership/ pulse/pulse-of-the-profession-2018.

Software advice, 2013. 14 project risk management tools that help manage life cycle uncertainty [online]. Available: https://www.saimgs.com/imglib/other_pages/Project\%20Management/14-pm-tools-to-manage-lifecycle/project_risk_management_tools-final.pdf

Soviar, Jakub; Holubcik, Martin; Vodak, Josef, 2018. Regional Cooperation Ecosystem: Case of the Zilina Self-Government Region (Slovak Republic). In: SUSTAINABILITY Volume: 10 Issue: 7 DOI: 10.3390/su10072219.

Zhang, YJ., Liu, S., Tan, J., Jiang, GY, Zhu, Q, 2018. Effects of risks on the performance of business process outsourcing projects: The moderating roles of knowledge management capabilities. International journal of project management. vol. 36 (4), pp. 627-639. 